\title{
Acyl-lupeol Esters from Parahancornia amapa (Apocynaceae)
}

\author{
Mário G. de Carvalho ${ }^{a *}$, Carlos R. X. Velloso ${ }^{a}$, Raimundo Braz-Filho ${ }^{b}$ and William F. da Costa \\ ${ }^{a}$ Departamento de Química, Instituto de Ciências Exatas, Universidade Federal \\ Rural do Rio de Janeiro, 23851-970, Seropédica - RJ, Brazil \\ ${ }^{\mathrm{b}}$ Setor de Química de Produtos Naturais, LCQUI, CCT, Universidade Estadual \\ Norte Fluminense, 28015-620, Campos - RJ, Brazil \\ ${ }^{\mathrm{c}}$ Departamento de Química, Universidade Estadual de Maringá, Maringá - PR, Brazil
}

\begin{abstract}
Das raízes de Parahancornia amapa, família Apocynaceae, foram isolados e identificados nove novos e dez conhecidos ésteres $3 \beta$ - $O$-acil lupeóis, os esteróides $\beta$-sitosterol, stigmasterol e $\beta$-sitosterona e os triterpenos $\beta$-amirina, $\alpha$-amirina, lupeol e seus derivados acetilados. As estruturas das substâncias foram deduzidas através da análise de dados espectroscópicos, principalmente RMN ${ }^{1} \mathrm{H}$ e ${ }^{13} \mathrm{C}$ (HBBD e DEPT). Os ésteres metílicos dos ácidos obtidos através da hidrólise dos acil lupeóis e metilação foram caracterizados por CG-EM.
\end{abstract}

From the roots of Parahancornia amapa, family Apocynaceae, the following compounds were isolated and identified nine new and ten known 3 $\beta$ - $O$-acyl lupeol esters, $\beta$-sitosterol, stigmasterol, $\beta$-sitosterone, the triterpenoids $\beta$-amyrin, $\alpha$-amyrin, lupeol and their acetyl derivatives. The structures of these compounds were established by spectroscopic data, mainly ${ }^{1} \mathrm{H}$ and ${ }^{13} \mathrm{C}$ (HBBD and DEPT) NMR spectra. The methyl esters obtained by hydrolysis of acyl lupeol esters and methylation of the corresponding acids were characterized by MS-GC analysis.

Keywords: Parahancornia amapa, Apocynaceae, acyl-lupeol

\section{Introduction}

Parahancornia amapa (Huber) Ducke, family Apocynaceae, is a tree which occurs in the Brazilian Amazonian region in the Amapa state. It is known as "amapa" or "amapazeiro" and the bark and latex are used by the natives as a tonic and anti-syphilis medicine ${ }^{1}$. The previous and only paper involving the phytochemical study of this species reported the presence of friedelin, lupeol, $\beta$-amyrin, $\alpha$-amyrin and their acetyl derivatives, four $3 \beta-O$-acyl lupeol, two $3 \beta-O-$ 3'-hydroxiacyl lupeol and two 3ß-O-3',5'-dihydroxyacyl lupeol in the bark and latex. Furthermore, triterpene fatty acid esters were also identified in plants 2,3 .

In this paper we report the occurrence of all the compounds above in the roots of this species, along with the known steroids $\beta$-sitosterol, stigmasterol and $\beta$-sitosterone and nine new $3 \beta$-O-acyl lupeol esters. The structures of these compounds were established by spectroscopic data, mainly ${ }^{1} \mathrm{H}$ and ${ }^{13} \mathrm{C}$ (HBBD and DEPT) NMR spectra. The methyl esters obtained by hydrolysis of

\footnotetext{
*e-mail: mgeraldo@ufrrj.br.
}

acyl lupeol esters and methylation of the corresponding acids were characterized by MS-GC.

\section{Experimental}

\section{General experimental procedures}

Melting points are uncorrected. The ${ }^{1} \mathrm{H}$ and ${ }^{13} \mathrm{C}$ NMR spectra were recorded on a Varian Unity 400 spectrometer $\left({ }^{1} \mathrm{H}\right.$ : $\left.400 \mathrm{MHz},{ }^{13} \mathrm{C}: 100 \mathrm{MHz}\right)$, and a Bruker Ac-200 $\left({ }^{1} \mathrm{H}: 200 \mathrm{MHz}\right.$, ${ }^{13} \mathrm{C}$ : $50.3 \mathrm{MHz}$ ) using $\mathrm{CDCl}_{3}$ as solvent and TMS as internal standard. The MS-GC analyses were carried out with a Shimadzu QP 2000A, EI 70eV, with hyperbolic quadrupole using split mode (1:10), source temp. $250^{\circ} \mathrm{C}$, column DB1 (50 m x $0.25 \mathrm{~mm}$ I.D. x $0.33 \mu \mathrm{m}$ film thichness), initial temp $100^{\circ} \mathrm{C} / 30^{\circ} \mathrm{C} \mathrm{min}^{-1} / 200^{\circ} \mathrm{C} / 10^{\circ} \mathrm{C} \mathrm{min}^{-1} / 300^{\circ} \mathrm{C}$. Column flow $1.65 \mathrm{~mL} \mathrm{~min}^{-1}$ and carrier gas Hellium. $\mathrm{CHCl}_{3}$ was used as solvent. FT-IR spectra were recorded in $\mathrm{KBr}$ discs on a PerkinElmer 1600 spectrometer. Chromatography was performed using silica gel (Merck and Aldrich) for column and preparative TLC. The purity of the compounds was checked by ${ }^{1} \mathrm{H}$ and ${ }^{13} \mathrm{C}$ NMR spectral analysis and TLC plate, developed with UV (254 and $366 \mathrm{~nm}$ ) and exposure to iodine vapour. 


\section{Plant material}

Roots of $P$. amapa were collected from one specimen identified by botanist Benedito Vitor Rabello in Amapá state, Brazil. The voucher specimen (nb 07231) is deposited in the Herbário Amapaense (HAMAB) of the Divisão de Botânica do Museu Ângelo Moreira da Costa Lima, Instituto de Estudos e Pesquisas do Amapá (IEPA), Macapá-AP, Brasil.

\section{Extraction and isolation of constituents}

The pulverized bark (470 g) and wood (800 g) from roots were extracted by maceration with hexane and methanol at room temperature. The solutions obtained were concentrated under vacuum to afford the residues PACRH (11.1 g, from the bark) and PARH (55.4 g, from the wood) from hexane and PACRM (8.0 g, from the bark) and PARM (30.0 g, from the wood) from methanol extracts. Both methanol residues were analyzed by IR and ${ }^{1} \mathrm{H}$ and ${ }^{13} \mathrm{C}$ NMR spectra that revealed the presence of a carbohydrate mixture. A part of the residue PARH was recrystallized from hexane:AcOEt to yield two fractions PARH-1 (20.0 mg) and PARH-2 (30.0 mg), which were examined by both TLC (hexane-EtOAc, 9:1) and spectrometric analysis to reveal the presence of a mixture of $\beta$-sitosterol and stigmasterol in PARH-1 and a mixture of $\beta$-sitosterone, lupeol, $\beta$-amyrin and $\alpha$-amyrin in PARH-2. The PACRH residue was recrystallized from acetone to yield PACRH-1 and PACRH-2. TLC and spectrometric analysis showed the presence of a mixture of the lupeol, $\beta$-amyrin and $\alpha$-amyrin acetates in PACRH-1 and a mixture of $\mathbf{2}+\mathbf{3}+\mathbf{4}$ in PACRH-2. $80.0 \mathrm{mg}$ of PACRH-2 was chromatographed by preparative TLC (hexane-EtOAc, 9:1) furnishing 2 (40 $\mathrm{mg}$ ) and $\mathbf{3}(25 \mathrm{mg})$.

\section{$\beta$-Sitosterol and stigmasterol}

Mp 139-141 ${ }^{\circ} \mathrm{C}$, hexane-EtOAc. These compounds were identified by ${ }^{1} \mathrm{H}$ and ${ }^{13} \mathrm{C}$ (HBBD and DEPT) NMR spectral analysis and by comparison with literature data ${ }^{4,6}$.

\section{$\beta$-Sitosterone, lupeol, $\beta$-amyrin and $\alpha$-amyrin}

Mp 152-154 ${ }^{\circ} \mathrm{C}$, acetone. The presence of these three triterpenes and of the steroid in a mixture was revealed by spectral data, mainly ${ }^{13} \mathrm{C}$ NMR (HBBD and DEPT) and ${ }^{1} \mathrm{H},{ }^{13} \mathrm{C} \mathrm{COSY}$, and by comparison with literature data ${ }^{1,5}$. The MS-GC analysis of this mixture showed the presence of two peaks at $\mathrm{m} / \mathrm{z} 426$ and 412 corresponding to the $\mathrm{M}^{+}$. of isomeric triterpenes and $\beta$-sitost-4-en-3-one, respectively. This steroid was also identified with the help of a MS/GC library.
Acetates of $\beta$-amyrin, $\alpha$-amyrin and lupeol (1)

Mp 139-141 ${ }^{\circ} \mathrm{C}$, acetone. These triterpenes were identified by spectral data, mainly ${ }^{13} \mathrm{C}$ NMR (HBBD and DEPT) and comparison with the chemical shifts described in the literature ${ }^{1,5}$.

\section{Mixture of triterpenoid esters $2+3+4$}

Mp 58-60 ${ }^{\circ} \mathrm{C}$, acetone. $v_{\max } / \mathrm{cm}^{-1}(\mathrm{KBr}),,{ }^{1} \mathrm{H}$ and ${ }^{13} \mathrm{C}$ $\mathrm{NMR}\left(\mathrm{CDCl}_{3}\right)$ were identical to literature values ${ }^{1}$.

\section{Hydrolysis of the esters of the $2+3+4$ mixture}

The mixture (100.0 mg) was treated with $20 \% \mathrm{NaOH}$ in $\mathrm{MeOH}(5 \mathrm{~mL})$, refluxed for $2 \mathrm{~h}$ and extracted with ethyl ether. The solvent was removed by evaporation and the residue obtained was chromatographed on a silica gel column to furnish a mixture of carboxylic acids $\left(43.0 \mathrm{mg}, \mathrm{mp} 126-128^{\circ} \mathrm{C}\right)$. This mixture $\left(26 \mathrm{mg}\right.$ ) was treated with $\mathrm{CH}_{2} \mathrm{~N}_{2}$ previously prepared from Diazald to yield a methyl esters mixture $(26.0 \mathrm{mg}, \mathrm{mp}$ $\left.111-113^{\circ} \mathrm{C}\right)$. The mixture of methyl esters was submitted to MS-GC analysis and $\mathbf{2 a}-\mathbf{2 j}, \mathbf{3 a}-\mathbf{3 e}, \mathbf{4 a}$ e $\mathbf{4 b}$ were identified.

\section{Acetylation of 3}

$40.0 \mathrm{mg}$ of $\mathbf{3}$ was dissolved in a mixture of pyridine and $\mathrm{Ac}_{2} \mathrm{O}(1: 1)$ and the solution was maintained for $24 \mathrm{~h}$ at room temperature. The usual work up and crystallization from methanol yielded 3Ac. $\left(28.0 \mathrm{mg}, \mathrm{mp} 59-61^{\circ} \mathrm{C}\right)$. This acetyl derivative was identified by ${ }^{1} \mathrm{H}-\mathrm{NMR}(200 \mathrm{MHz}$, $\mathrm{CDCl}_{3}$ ) and ${ }^{13} \mathrm{C}-\mathrm{NMR}\left(50 \mathrm{MHz}, \mathrm{CDCl}_{3}\right.$ ) spectral data by comparison with the values described in the literature ${ }^{1}$.

\section{Oxidation of $\mathbf{3}$}

Pyridinium chlorochromate suspended in dry $\mathrm{CH}_{2} \mathrm{Cl}_{2}$ (40\%, $7 \mathrm{~mL}$ ) was added to $40.0 \mathrm{mg}$ of 3 and stirred for $3 \mathrm{~h}$. The black reaction mixture was filtered on a florisil column. The solvent was removed under reduced pressure and the 3oxo product obtained $\left(31.0 \mathrm{mg}\right.$, mp $\left.57-59^{\circ} \mathrm{C}\right)$ was characterized as a tautomeric mixture of 5, 6 and $\mathbf{7 .}$ ${ }^{1} \mathrm{H} \mathrm{NMR}\left(200 \mathrm{MHz}, \mathrm{CDCl}_{3}\right) \delta_{\mathrm{H}} 0.84\left(t, 6.0 \mathrm{~Hz}, \mathrm{CH}_{3}-\mathrm{CH}_{2}\right.$, 5-7), $1.22\left[m,\left(\mathrm{CH}_{2}\right)_{\mathrm{n}}\right.$, 5-7], $2.49(t, 6.0 \mathrm{~Hz}, 2 \mathrm{H}-4$ '), $3.40(s$, $2 \mathrm{H}-2$ ', 5), 4.52 ( $m, \mathrm{H}-3), 4,53$ and 4.57 ( $s, \mathrm{H}-29 \mathrm{a}$ and $\mathrm{H}-29 \mathrm{~b})$, 4.90 ( $s, \mathrm{H}-2$ ', 6 and 7), together with additional signals corresponding to lupeol; ${ }^{13} \mathrm{C} \mathrm{NMR}\left(50 \mathrm{MHz}, \mathrm{CDCl}_{3}\right) \delta_{\mathrm{C}} 202.0$ (C-3'), 173.5 (C-1'), $82.1(\mathrm{CH}-3)$ and $49.5\left(\mathrm{CH}_{2}{ }^{2}{ }^{\prime}\right)$ of 5; 178.6 (C-3'), 166.9 (C-1'), 89.2 (CH-2'), 82.1 (CH-3), 43.0 $\left(\mathrm{CH}_{2}{ }^{-4}{ }^{\prime}\right)$ of 6; 194.9 (C-3'), 172.6 (C-1'), 89.2 (CH-2'), 80.3 (CH-3), $43.0\left(\mathrm{CH}_{2}-4^{\prime}\right)$ of 7 ; and additional signals corresponding to lupeil moiety and a long hydrocarbon chain which are in accordance with literature data ${ }^{1}$. 


\section{Results and Discussion}

The known natural products (see experimental) were identified by analysis of their ${ }^{1} \mathrm{H}$ and ${ }^{13} \mathrm{C}$ NMR data, MSGC analysis and comparison with literature data ${ }^{1,4-6}$. $\beta$-sitosterol, stigmasterol and $\beta$-sitosterone are being reported for the first time in this species. Lupeol (1), $\beta$-amyrin, $\alpha$-amyrin and their acetyl derivatives were previously isolated from the latex of a specimen of P. amapa ${ }^{1}$. From the bark and latex of this specimen esters 2E, 2G, 2I, 2J, 3B, 3C, 3D and $3 \mathrm{E}^{1}$ were also isolated.

In this paper we describe the characterization of the new triterpenoid esters 2A - 2D, 2F, 2H, 3A, 4A and isolation of $4 \mathrm{~B}$ from the roots of $P$. amapa.

The presence of these esters $(\mathbf{2}-\mathbf{4})$ in a mixture was observed by analysis of IR, ${ }^{1} \mathrm{H}$ and ${ }^{13} \mathrm{C}$ NMR spectra, involving comparison with data obtained by detailed analysis of the esters isolated from the latex of the same plant ${ }^{1}$. The acyl groups in the esters were identified by MS-GC analysis of the methyl esters prepared by methylation of the acids furnished by alkaline hydrolysis of the natural substances. The mass spectrum of each of the 18 intense peaks observed in the gas chromatogram (Table 1) was analyzed. Besides the presence of butyl phthalate $(\mathbf{X})$ as a contaminant, ten $(\mathbf{2 a}-\mathbf{2} \mathbf{j})$ of $\mathbf{2}$, five (3a - 3e) of 3 and two (4a and $\mathbf{4 b}$ ) of $\mathbf{4}$ methyl esters were identified. The main peaks observed in the mass spectra of the methyl esters $[\mathrm{m} / \mathrm{z}(\%): 74(100)$ and $87(65-70)$ of $\mathbf{2}$; 103 (100) of 3; 97 (70) and 115 (40) of 4] were used to characterize the nature of the acyl moieties. The equation

Table 1. Retention time ( $t_{\mathrm{R}}$ in GC-MS) and percentages (\%) of the identified methyl esters.

\begin{tabular}{|c|c|c|c|c|c|c|c|c|c|}
\hline \multicolumn{5}{|c|}{ Methyl esters } & \multicolumn{5}{|c|}{ Methyl esters } \\
\hline$t_{R}$ & 2 & 3 & 4 & $\%$ & $t_{R}$ & 2 & 3 & 4 & $\%$ \\
\hline 15.42 & $2 \mathbf{a}\left(\mathrm{C}_{16}\right)$ & & & 3.84 & 21.85 & & $3 \mathbf{c}\left(\mathrm{C}_{22}\right)$ & & 11.23 \\
\hline 16.77 & $2 \mathbf{b}\left(C_{18}\right)$ & & & 2.22 & 22.16 & $2 \mathbf{g}\left(\mathrm{C}_{24}\right)$ & & & 5.77 \\
\hline 17.98 & & $\mathbf{3 a}\left(\mathrm{C}_{18}\right)$ & & 2.25 & 23.15 & & & $\mathbf{4 a}\left(\mathrm{C}_{25}\right)$ & 2.40 \\
\hline 18.28 & $2 \mathbf{c}\left(\mathrm{C}_{20}\right)$ & & & 5.77 & 23.35 & $\mathbf{2 h}\left(\mathrm{C}_{25}\right)$ & & & 0.93 \\
\hline 19.06 & $2 \mathbf{d}\left(\mathrm{C}_{21}\right)$ & & & 1.55 & 24.51 & & $\mathbf{3 d}\left(\mathrm{C}_{24}\right)$ & & 8.64 \\
\hline 19.72 & & $3 \mathbf{b}\left(\mathrm{C}_{20}\right)$ & & 14.16 & 24.95 & $\mathbf{2 i}\left(\mathrm{C}_{26}\right)$ & & & 4.42 \\
\hline 20.02 & $2 \mathbf{e}\left(\mathrm{C}_{22}\right)$ & & & 10.45 & 26.47 & & & $\mathbf{4 b}\left(\mathrm{C}_{26}\right)$ & 2.16 \\
\hline 20.48 & $n$-Butyl phthalate $(\mathbf{X})$ & & & 18.35 & 28.16 & & $\mathbf{3 e}\left(\mathrm{C}_{26}\right)$ & & 2.66 \\
\hline 20.97 & $\mathbf{2 f}\left(\mathrm{C}_{23}\right)$ & & & 0.97 & 28.84 & $2 \mathbf{j}\left(\mathrm{C}_{28}\right)$ & & & 2.23 \\
\hline
\end{tabular}

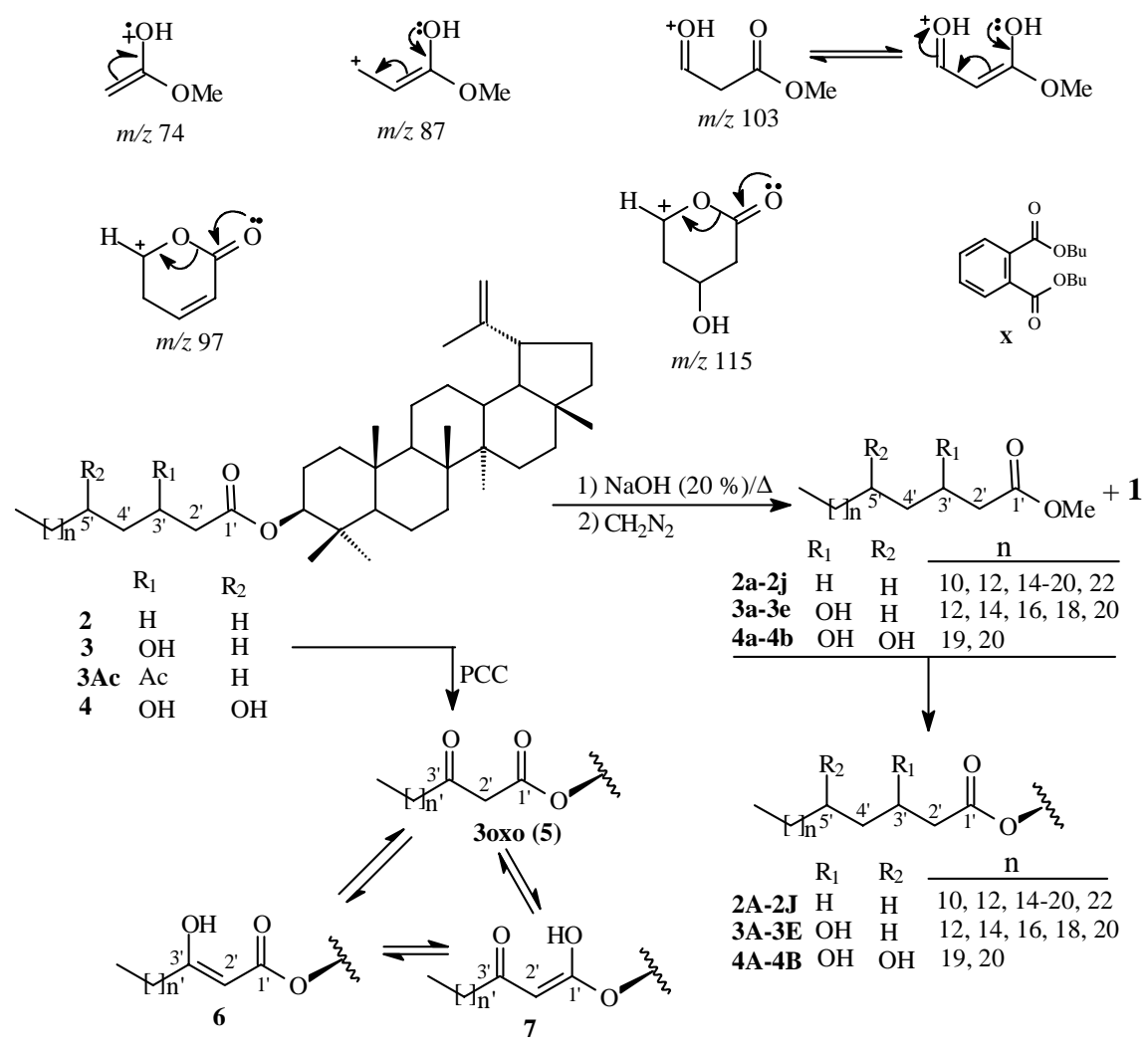


$74+14 \mathrm{n}+15=\mathrm{M}^{+\cdot}$ was used to define the number of methylene groups ( $n=10,12,14-20$ and 22$)$ of the methyl esters $\mathbf{2 a - 2 j}$. The peaks observed in the mass spectra of $\mathbf{3 a}$ $(\mathrm{m} / \mathrm{z} 296,2 \%, \mathbf{M}-18), \mathbf{3 b}(\mathrm{m} / \mathrm{z} 343,0.4 \%, \mathbf{M}+1$ and 324 , $1 \%, \mathrm{M}-18), \mathbf{3 c}(\mathrm{m} / \mathrm{z} 371,11 \%, \mathrm{M}+1$ and $352,10 \%, \mathrm{M}$ - 18), 3d (399, $4 \%, M+1$ and 381, $31 \%, M-17), 3 e$ $(\mathrm{m} / \mathrm{z}, 426,4 \%, \mathbf{M}$ and $408,2 \%, \mathbf{M}-18), \mathbf{4 a}(\mathrm{m} / \mathrm{z} 429,0,5$ $\%, \mathrm{M}+1$ and $281,10 \%,\left[\mathrm{C}_{20} \mathrm{H}_{41}\right]^{+}$and $148,5 \%$, methyl 3,5-dihydroxypentanoate) and $\mathbf{4 b}(\mathrm{m} / \mathrm{z} 406,1 \%$, methyl hexaeicosa-2,4-dienoate) were used to define the acyl moieties of 3 and $\mathbf{4}$. Table 1 shows the retention time $\left(t_{R}\right)$ and the relative percentage of each methyl ester identified in the mixture. The methyl esters were used to identify the acyllupeol esters 2A - 2J, 3A - 3E, 4A and 4B.

A mixture of $\mathbf{2}$ and $\mathbf{3}$ was separated by preparative TLC and the acetyl derivative $3 \mathrm{Ac}$ was prepared. The ${ }^{1} \mathrm{H}$ and ${ }^{13} \mathrm{C}$ (HBBD and DEPT) NMR spectra of this mixture were practically identical to those of the 3'-acetyl-acyllupeol prepared with the ester isolated from the latex of the same species ${ }^{1}$. Oxidation of $\mathbf{3}$ with $\mathrm{PCC}$ in $\mathrm{CH}_{2} \mathrm{Cl}_{2}$ afforded the $\beta$-ketoester derivative (3oxo). The $1 \mathrm{D}{ }^{1} \mathrm{H}$ and ${ }^{13} \mathrm{C}$ NMR (HBBD and DEPT) and $2 \mathrm{D}{ }^{1} \mathrm{H}_{-}{ }^{13} \mathrm{C}-\mathrm{COSY}-{ }^{\mathrm{n}} J_{\mathrm{CH}}(\mathrm{n}=1$, HETECOSY; $n=2$ and 3, COLOC) shift-correlated spectra of this product allowed to identify 5 together with the enols 6 and 7 (See experimental).

\section{Acknowledgements}

The authors are grateful to CNPq and CAPES for a research fellowship and for support from Conselho Nacional de Desenvolvimento Científico e Tecnológico (CNPq), Financiadora de Estudos e Projetos (FINEP) and Fundação de Amparo ‘a Pesquisa do Estado do Rio de Janeiro (FAPERJ).

\section{References}

1. Sobrinho, D. C.; Hauptli, M. B.; Appolinário, E. V.; Kollenz, C. L. M.; Carvalho, M. G. de; Braz-Filho, R. J. Braz. Chem. Soc. 1991, 2, 15.

2. Buckingham, J. Dictionary of Natural Products; Chapman \& Hall, London, 1994, p. 5988.

3. Oksuz, S.; Topcu, G. Phytochemistry 1987, 26, 3082.

4. Kojima, H.; Sato, N.; Hatano, A.; Ogura, H. Phytochemistry 1990, 29, 2351.

5. Olea, R. S. G.; Roque, N. F. Quím. Nova 1990, 13, 278.

6. Chaurasia, N.; Wchtl, M. J. Nat. Prod. 1987, 50, 881.

Received: October 11, 2000

Published on the web: June 29, 2001 